INDEPENDENT JOURNAL OF MANAGEMENT \& PRODUCTION (IJM\&P)

http://www.ijmp.jor.br $\quad$ v. 11, n. 5, Special Edition IFLOG 2019 -September 2020 ISSN: 2236-269X

DOI: 10.14807/ijmp.v11i5.1290

\title{
THE RELATIONSHIP BETWEEN ADDITIVE MANUFACTURING AND CIRCULAR ECONOMY: A SISTEMATIC REVIEW
}

Thais Moreira Tavares

Federal University of São Carlos, Brazil

E-mail: thaism0405@gmail.com

Moacir Godinho Filho

Federal University of São Carlos, Brazil

E-mail:moacir@dep.ufscar.br

Gilberto Devós Ganga

Federal University of são carlos, Brazil

E-mail: ganga@dep.ufscar.br

Mário Henrique callefi

Federal University of são carlos, Brazil

E-mail: mariocallefi@gmail.com

Submission: $3 / 3 / 2020$

Revision:4/3/2020

Accept:3/11/2020

\section{ABSTRACT}

One of the important technologies in Industry 4.0 is Additive Manufacturing, which makes it possible to manufacture objects layer by layer continuously or incrementally. Circular economy aims to improve resource efficiency, leading to an evolution from the current linear model of extraction, transformation, and elimination to the model where resources flow in a circular manner. Many early studies have pointed to Additive Manufacturing as a technology that promises the environmental sustainability and the development of circular material flows. However, there is still great uncertainty about the relationship between circular economy goals and 3D printing goals. From this context, a Systematic Literature Review was performed by applying the Method Ordination multicriteria methodology in order to map the main publications. Then, 10 articles were analyzed to obtain relevant information about the relationship between Additive Manufacturing and Circular Economy.

Keywords: Additive manufacturing; Circular economy; Systematic Review 
DOI: 10.14807/ijmp.v11i5.1290

\section{INTRODUCTION}

The manufacturing processes comprise several moments since the beginning of the advance of the industrial era, which took place in England in the 18th century. Since that time, technology has advanced so that its evolution is divided into phases, called industrial revolutions.

The first Industrial Revolution can be defined as the era of mechanization. The second, stood out for its intensive use of electric energy; and the third for the widespread digitalization. More recently, based on advanced digitization within the factories, the reconciliation of internet technologies and future-oriented technologies in the field of "smart" objects (machines and products) seems to result in a paradigm shift in industrial production. Representing the future expectations, the term "Industry 4.0" was created to refer to a fourth industrial revolution (LASI et al., 2014)

The concept of Industry 4.0 is quite new. It was launched in Germany in 2011 representing the current production paradigm, which combines information and communication technologies with digital production technologies (KANG et al., 2016).

According to Shrouf et al. (2014), the main characteristic of industry 4.0 is the connectivity between machines, orders, employees, suppliers and customers due to the Internet of things and electronic devices. Kang et al. (2016) includes in the main industry 4.0 technologies: internet of things, big data, data analysis, Cyber-Physical systems (CPS) and systems integration, sustainable manufacturing and Additive Manufacturing (AM).

Shipp et al. (2012) suggests one of the technologies that should be highlighted is Additive Manufacturing, since in recent years the intensification of competition, combined with the challenge of increasing the complexity of manufactured products has required companies and designers to substantially change the process of product development. In this context, interest in so-called Additive Manufacturing (AM) or 3D printing processes is growing.

Additive manufacturing is defined by the ISO / ASTM terminology standard as the "process of joining materials to manufacture parts from 3D model data, usually layer upon layer, as opposed to subtraction and formative manufacturing methodologies” (ASTM, 2013). This requires the use of a computer to translate a solid model into a real part. In other words, 3D printing allows objects to be manufactured layer by layer in a continuous or incremental manner, allowing three-dimensional objects to be "printed" on demand (PETROVIC et al., 2011). 
DOI: 10.14807/ijmp.v11i5.1290

The development of cheap 3D printing hardware has equipped consumers with tools that allow them to influence product innovation and manufacturing processes. However, with a forecast of rapid growth in the near future and the technology maturing, 3D printing is likely to result in a significant product output and therefore also a significant environmental impact (CERDAS et al., 2017).

This impact of technological advances can bring potential benefits to sustainability (GEBLER et al., 2014). Such benefits include the potential to move towards a Circular Economy (CE), which aims to radically improve the efficiency of society's resources, eliminating the concept of waste and changing from the linear model of take-make-waste to a circular model (DESPEISSE et al., 2017).

Yuan et al. (2006) say the core of the circular economy is the circular flow of materials and the resources and energy use through multiple phases. The circular economy is beneficial to society and the economy as a whole, since it can reduce the use of the natural environment as a waste sink and reduce the use of virgin materials for economic activities (ANDERSEN, 2007).

According to Loy and Tatham (2016), the relationship between the objectives of circular economy and the economy of 3D printing as a production system is just beginning to be articulated in the literature.

There is great doubt whether the current trajectory of adopting additive manufacturing is creating more circular material flows or leading to an alternative scenario in which localized production is less eco-efficient. Therefore, it is still unclear whether 3D printing technology can realistically allow a more circular use of resources, and under what circumstances they are truly beneficial from the point of view of sustainability (DESPEISSE et al., 2017).

Evans et al. (2009) argues this clarity requires a better understanding of information flows and of the relationships between stakeholders throughout the product and material life cycles.

According to Despeisse et al. (2017) and Unruh (2018) it is essential that the principles of CE are incorporated into the new manufacturing system before the adoption of AM reaches a critical turning point in which negative practices entrench themselves.

In addition, according to Loy and Tatham (2016), even less has been debated about the effects of the circular economy in the context of a production based on Additive Manufacturing.

In view of these current studies, it can be seen that there is a two-way gap in the literature on the relationship between Additive Manufacturing and Circular Economy. In other 
DOI: 10.14807/ijmp.v11i5.1290

words, how Additive Manufacturing influences and Circular Economy and how Circular Economy influences Additive Manufacturing are little studied relations.

Given the previously presented, the present work aims to fill this gap and has the objective of describe the general effects of the relationship between Additive Manufacturing and Circular Economy. Within this proposed context, it is define the research question to be explored through a Systematic Review of the Literature: what are the effects of the relationship between Additive Manufacturing and Circular Economy?

\section{ADDITIVE MANUFACTURING}

This subsection presents a brief history of the emergence of AM, its definition and AM stages.

\subsection{Brief history of AM}

According to Bourell, Rosen and Leu (2014), the first records on the use of threedimensional technologies to create objects, date back to the second half of the 19th century, more precisely in 1860, when François Willème conducted initial trials in the creation of replicas of 3D objects. He was a then French artist from Paris who was developing photosculture. Willème used the newly invented photography and combined it with the principles of optics and sculpture to create three-dimensional replicas of objects and even people (ZHAI et al., 2014).

From this technique, others were developed. Then, in the late 1980s and early 1990s, 3D technology was finally patented and commercialized by companies such as 3D System, Stratasys and EOS (BANDYIPADHYAY et al., 2015). Ruffo et al. (2006) point out that these technologies were called for many years rapid prototyping tools. However, technological maturation has stimulated the development and use of 3D technology for rapid manufacturing, and not just for the prototype.

Despite this development, even today the use of 3D printing for the final use of products and components is strongly limited to some industrial niches. For example, for the production of tools on the international space station the application is logical, but the commercial viability of manufacturing is still questionable in some cases (HOLWEG, 2015).

Since the commercialization of 3D technologies, its construction methods have been quite developed and diversified with the use of greater number and more refined processes, as well as sophisticated materials. 
DOI: 10.14807/ijmp.v11i5.1290

\subsection{AM definition}

Constructive layers are the basic principle of 3D printing, as it consists in the manufacture of an item from the deposition of a certain material in overlapping layers repeatedly until the complete part is obtained. Additive manufacturing differs from traditional production processes for not being subtractive. It means material is not removed progressively until the desired part is obtained; and this makes 3D printing a "disruptive" technology (KIETZMANN et al., 2015).

So, additive manufacturing can be understood as a technology that uses an additive process to manufacture three-dimensional objects, from a digital model (NYMAN; SARLIN, 2014). It means the printing of a complete product or part of a product using materials that are deposited within the limits of the printer. These machines can not only create objects without grooves, but also mold complex shapes resulting in a final product or an item that can be integrated into a set with other items (GRESS; KALAFSKY, 2015).

Modern AM technologies need to have four resources to achieve the creation of the three-dimensional object: a computerized system; a software for editing three-dimensional designs; an equipment with the ability to print in layers ; and the appropriate input resource to form the layers of the object to be created. In addition, the central principles of AM are the same in all technologies (SIN, 2016).

\subsection{AM Steps}

The three-dimensional printing process has common steps in all its variants and it starts in a virtual model of a part to be materialized. So, it does not matter the machine used to build the model.

The stages of the MA process are: digital or design, manufacturing or printing and post process (KIETZMANN et al., 2015). They are explained below:

- Digital or Design: This stage is formed by two main activities: Computer Aided Design (CAD) and Standard Triangle Language (STL) (KIETZMANN et al., 2015). In this way, the user creates his project in 3D drawing by computer in the CAD phase and in the next phase he exports the project to an STL file extension, which is a legible 3D printing form.

- Manufacturing or Printing: In this stage, the machine is configured and the part is produced. That is, before printing layer by layer, it is necessary to have a machine configuration to adapt the print nozzle (KIETZMANN et al., 2015). 
- Post-process: In this step, post-processing is performed separately to create the final object. This is necessary because some operations require surface treatment or other manufacturing procedures in order to improve the shape of the printed objects (KIETZMANN et al., 2015).

\section{CIRCULAR ECONOMY}

We currently live in a linear economy model, but this has proven to be unsustainable, as it is based on the theory that resources are inexhaustible. In this model, first there is the extraction of resources from the ecosystem. From that, the products are fabricated and consumed. Finally, when they reach the end of their useful life, they are considered waste and eliminated without creating any additional value.

Therefore, The market economy assumes that natural resources are inexhaustible and inexpensive, disregarding the degradation of natural resources, as well as the growing accumulation of waste. This linear model is structured taking into account extraction, transformation and elimination. Thus, the move to a circular economy is essential for a smart, sustainable and inclusive growth.

Circular Economy aims to create circular flows of resources in the economy (as opposed to currently dominant linear flows ranging from resource extraction to landfill disposal). It is framed as an economic imperative rather than an environmental imperative. Also, it has been described at three special levels: The individual level of the company using cleaner production; Level of the eco-industrial park with grouped or linked industries (responsible supply chain); Between production and consumption systems in regions (YUAN et al., 2006). As such, the circular economy differs from industrial ecology through a more economical approach.

The concept of circular economy has deeply rooted origins and it is gaining more and more prominence, especially in China (MATHEWS, 2011). Its practical applications for modern economic systems and industrial processes, however, have gained strength since the 1970s by a small number of academics, thinkers and companies. The expression "Cradle to Cradle" (C2C), conceived by Stahel in the late 1970s, indicates the development of a "closed loop" approach to production processes (MACARTHUR, 2013).

The Ellen Macarthur Foundation's report (2013) highlights four sources of value creation for business models, in which initiatives to "close the cycle" of products can be very profitable: maintenance, redistribution, remanufacturing and recycling. A general illustration of the concept of circular economy is given in Figure 1: 
DOI: 10.14807/ijmp.v11i5.1290

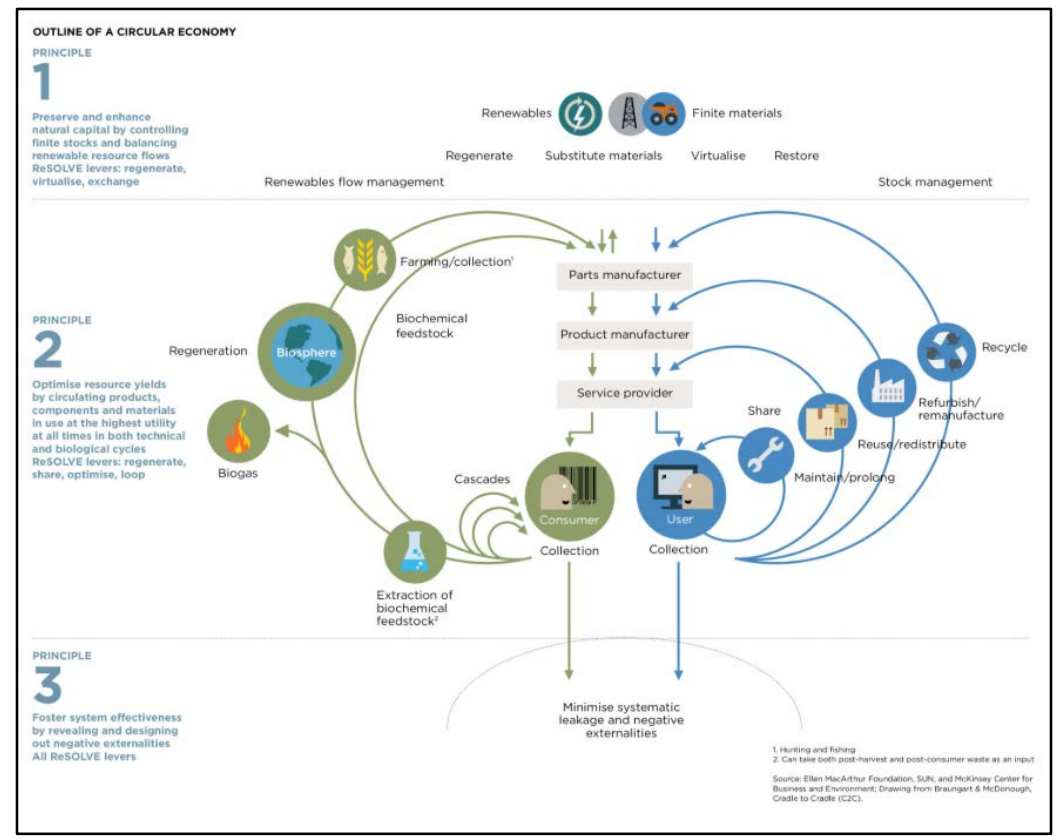

Figure 1: Circular economy for renewable and non-renewable resources.

Source: Ellen Macarthur Foundation report (2013).

The utility of cascading in Figure 1 is to illustrate that smaller loops (closer to the user) generally have less impact. The Ellen Macarthur Foundation Report (2013) further identifies that new business models will be part of the new economic approach and that the sources of value creation in a circular economy can be identified as:

a) Internal circles: offer greater substitution of embedded costs for materials, labor, energy;

b) Circulating longer: Through better design to make products last longer;

c) Cascading uses: like transformating old clothes made of fibers in furniture;

d) Pure and non-toxic inputs: to have purer material flows, improving the potential for reuse and recycling.

The last point in particular represents a point of tension between designing highperformance systems with inputs of complex materials that are also complex to recycle, rather than simpler systems that are simpler to recycle.

\section{RESEARCH METHODOLOGY}

Due to the amount of information currently available, there was a need to perform a literature review in order to cover a large number of works without favoring those aligned with the researchers' point of view (BADGER et al., 2000). 
According to Biolchinni et al. (2005), the systematic literature review (RSL) is a research approach that has well-defined steps, planned according to previously established protocol and objectives. The systematic review is recognized for being methodical, transparent and replicable, according to Cooper (1998). In some areas, such as medicine, the use of Systematic Review is quite frequent, however, recently other areas have also started to enter this type of research, such as management research (TRANFIELD et al., 2003).

This review is structured following the method described in the PRISMA statement (Preferred reporting items for systematic review and Meta-Analysis) (MOHER et al., 2009). The PRISMA flowchart reporting the different phases of this systematic literature review is shown in Figure 2.

The four stages of PRISMA that are performed in the Systematic Review are: Identification, Screening, Eligibility and Inclusion. In the first stage there is the identification of the relevant literature in the area and elaboration of the Strings developed in the databases to be used. In the next stage, of Screening, there is a selection of articles, removing nonadherent ones, according to inclusion and exclusion criteria. In the Eligibility stage, there is a full reading of previously filtered articles, with the removal of non-adherent articles. Finally, in the inclusion stage, articles are included in the quantitative and qualitative analysis.

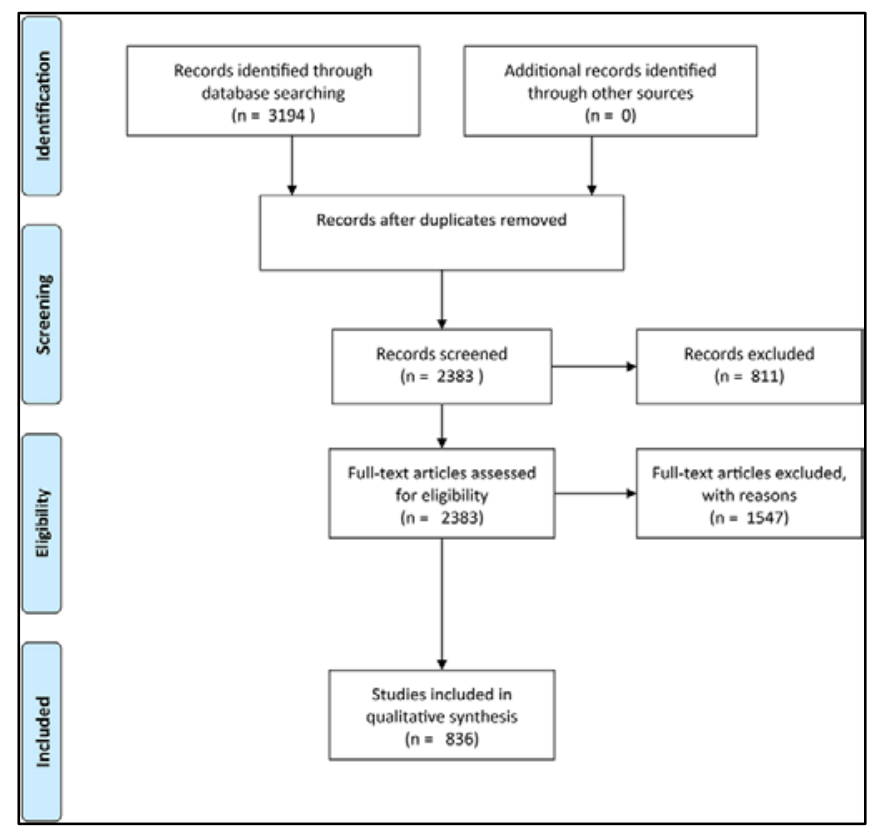

Figure 2: PRISMA flowchart Practical steps. Source: Adapted from Moher et al. (2009)

For this work, the multicriteria methodology Methodi Ordinatio was used to compose the bibliographic portfolio. Methodi Ordinatio is a multi-criteria decision-making methodology that was born from the need to qualify the articles obtained in a systematic bibliographic review 
DOI: 10.14807/ijmp.v11i5.1290

(PAGANI et al., 2015). After applying the filters, when there is already a defined article base, the calculation of InOrdinatio is performed.

Some authors, like Vinkler (2012), discuss the importance of a publication's impact factor. Bornmann (2010) and Antelman (2004) emphasize the importance of the number of citations, given the recognition by the scientific community. In addition, the year of publication is also seen with great relevance, since it is a parameter that evaluates the actuality of information and data. According to Pagani et al (2015) there is a high probability that the most current articles are based on methodologies which have already been validated, reinforcing the importance of extolling the most recent research.

Thus, the Methodi Ordinatio methodology was conceived based on these three analysis criteria identified in the literature: number of citations, impact factor and year of publication. After the criteria are identified, the articles are ordered by calculating the InOrdinatio, using the following equation:

InOrdinatio $=[(\mathrm{Fi} / 100) * \alpha *[10-($ apes-apub $)]+\mathrm{nc}]$

In the equation, the Impact Factor is divided by 1000 so its value is normalized against the other criteria. The weighting factor is given by $\alpha$ and is assigned by the researchers, varing from 1 to 10 . The closer to 1 , the lower the importance attributed by the researcher to the year of publication criterion and the closer to 10 , the greater the importance.

\subsection{Systematic literature review}

The main point of interest in this review is to investigate the link between Additive Manufacturing and Circular Economy. To achieve this goal, a simple conceptual framework was initially developed, in figure 3, to summarize the findings in the literature.

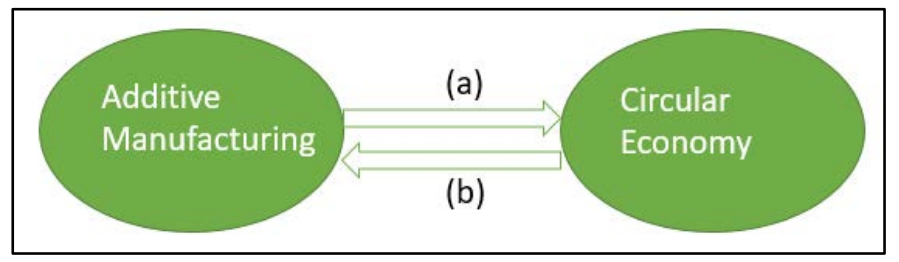

Figure 3: Relationship between additive manufacturing and circular economy. Source: Authors

From this, it was possible to elaborate the research questions, which, according to figure 3, are:

(a) How does Additive Manufacturing (AM) Enhance or Restrict the Circular Economy (CE)?

(b) How does the Circular Economy Enhance or Restrict Additive Manufacturing? 
From a literature search, the Keywords (table 1) were defined so the string were developed. For Additive Manufacturing, the various synonyms found in the literature were used as keywords and for Circular Economy, the principles of CE, found in the work of Ghisellini et al. (2016) were used.

Table 1: Search keywords

\begin{tabular}{|r|r|}
\hline For Additive Manufacturing & For Circular Economy \\
\hline \hline 3D printing OR & Circular Economy OR \\
3D printed OR & Share OR \\
Additive manufactured OR & Regenerate OR \\
Additive manufacturing OR & Optimise OR \\
Additive fabrication OR & Loop OR \\
Additive layered manufacturing OR & Virtualise OR \\
Additive processes OR & Exchange OR \\
Additive techniques OR & Virtual product Lifespan OR \\
Digital fabrication OR & Renewable energy OR \\
Digital manufacturing OR & Digital technologies OR \\
Direct Digital manufacturing OR & Recycle OR \\
Generative manufacturing OR & Reuse OR \\
Layer manufacturing OR & Reduction OR \\
Rapid prototype OR & Design \\
Rapid tooling OR & \\
Three dimensional printed OR & \\
Three dimensional printing & \\
& \\
\hline
\end{tabular}

Source: Authors.

From the keywords, the search strings were elaborated and inserted in 3 search engines or databases: Engineering Village, Scopus and Web of Science. After being inserted into each database, the strings returned the articles. Each database returned the following number of articles: Spcopus (337); Web of Science (219) and Engineering Village (128), as seen in Figure 4:

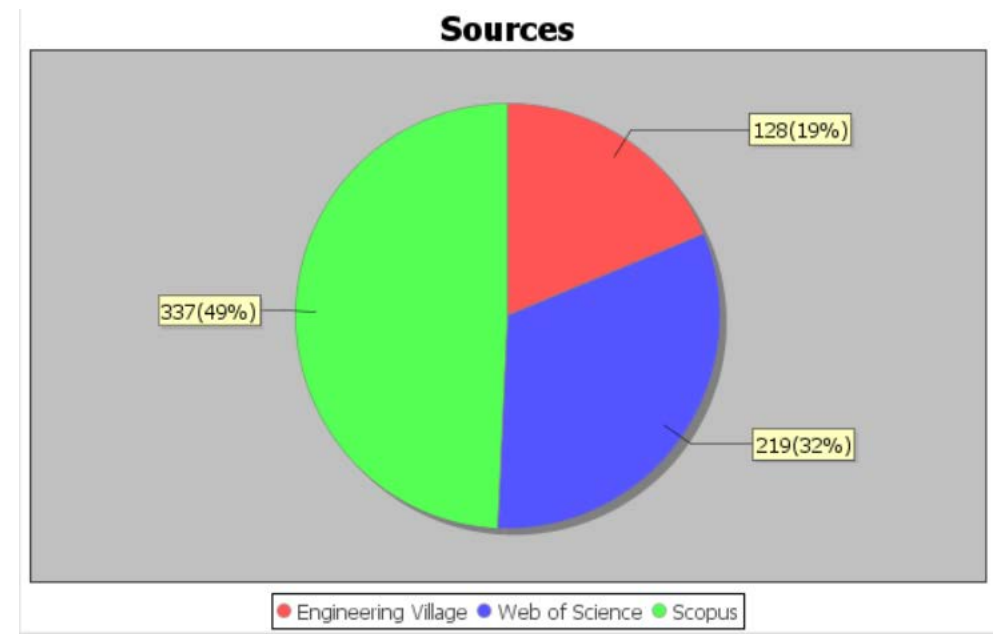

Figure 4: Number of documents returned in each database.

Source: Authors 
DOI: 10.14807/ijmp.v11i5.1290

Based on the strings, the databases returned 684 articles. After removing duplicate articles, 584 articles remained to be filtered applying the inclusion and exclusion criteria. Figure 5 shows the quantitative list of duplicate articles in the databases. As can be seen, the base that returned the greatest number of articles was Scopus; and the majority of duplicate articles were found in Scopus and Web of Science.

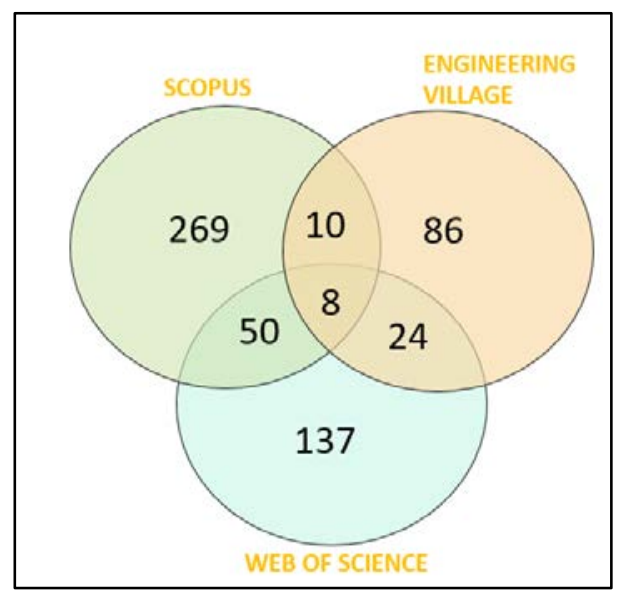

Figure 5: Quantitative relationship of duplication in the databases

Source: Authors

To ensure objective reasoning in the selected readings, the inclusion and exclusion criteria (BUER et al., 2018), presented in table 2, were used.

In the screening stage, the exclusion and inclusion criteria were applied to the articles returned from databases by reading the Abstract, keywords and title. Then 65 articles were selected for the full reading of the text in the next step. As can be seen in Figure 6, there has been an increasing trend in publications on the subject over the past few years. This trend in publications is proportional to the adoption curve of 3D printing in organizations (UNRUH, 2018). According to the aforementioned author, managers who want to guide their companies towards a sustainable future begin to turn their attention as the additive, distributed and circular future unfolds.

Table 2: Inclusion and Exclusion Criteria

\begin{tabular}{|c|c|}
\hline Inclusion Criteria & $\begin{array}{l}\text { (I-1) Partially relates to Additive Manufacturing and Circular Economy; } \\
\text { (I-2) Partially relates some circular economy construct to Additive } \\
\text { Manufacturing; } \\
\text { (I-3) Partially relates environmental factors to additive manufacturing; } \\
\text { (I-4) Strongly relates to Additive Manufacturing and Circular Economy; } \\
\text { (I-5) Strongly relates some circular economy construct to Additive } \\
\text { Manufacturing; } \\
\text { (I-6) Strongly relates environmental factors to additive manufacturing. }\end{array}$ \\
\hline Exclusion Criteria & $\begin{array}{l}\text { (E-1) The article is not from a journal; } \\
\text { (E-2) The article is not in English; }\end{array}$ \\
\hline
\end{tabular}




\begin{tabular}{|l|l|} 
(E-3) The article does not relate Additive Manufacturing to Circular \\
Economy or its constructs; \\
(E-4) The article is only loosely related to additive manufacturing or \\
circular economy.
\end{tabular} \mid

Source: Authors

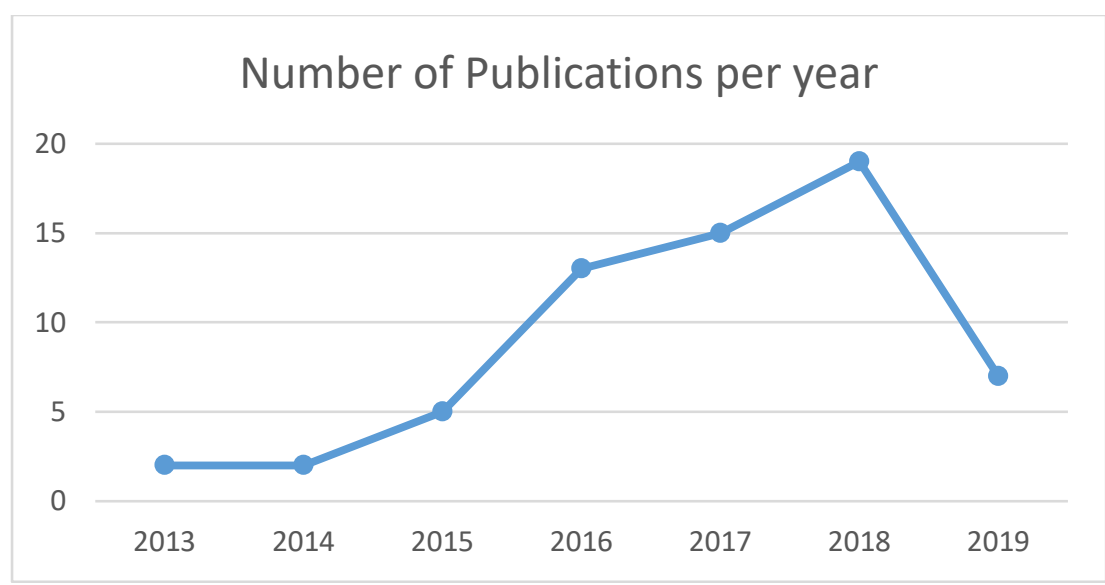

Figure 6: Number of Publications per year Source: Authors.

In the eligibility stage, the articles were fully read. Those who met all the inclusion criteria were considered in the systematic review in order to guarantee the quality of the selected materials (TRANFIELD et al., 2003). This filter resulted in 27 articles for final analysis, as shown in Figure 7.

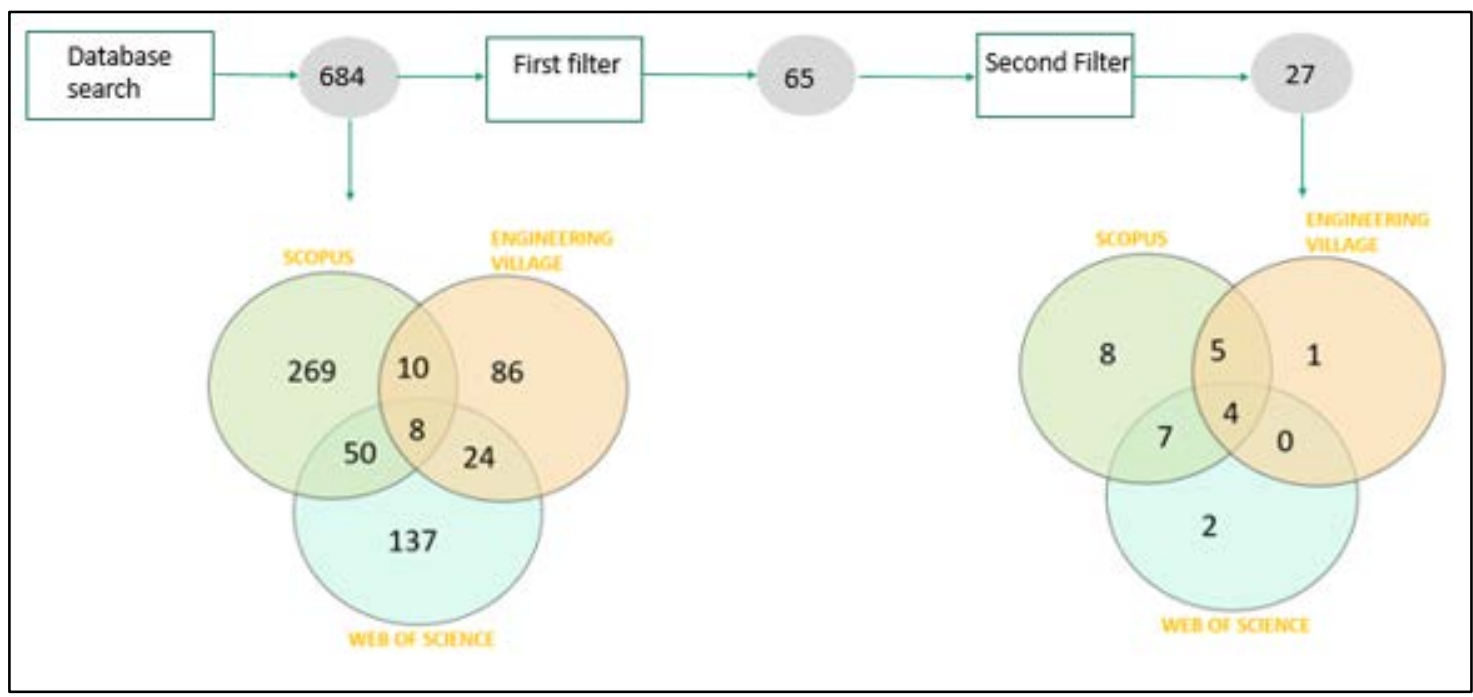

Figure 7: Summary of the search in the databases

Source: Authors.

24 out of the 27 articles to be included in the analysis can be found on Scopus database. This result was verified by inserting all titles in the Scopus database one by one. Replicating the insertion of the titles of articles accepted in the other two databases, it was possible to verify the contribution of each one in the present review (figure 7). This result demonstrated the 
ISSN: 2236-269X

DOI: 10.14807/ijmp.v11i5.1290

Scopus database was the most relevant academic database for finding articles related to the relationship between AM and CE among the bases considered.

The inclusion stage represents the analysis, synthesis and communication of the results of the two proposed questions. For this, the content analysis methodology is applied, following Krippendorff (2018). This step is recommended to facilitate the rigorous exploration of complex issues in management area (DURIAU et al., 2007).

In the inclusion stage, an ordering of the articles was made through the In Ordination calculation, with an $\alpha$ equal to 10 . After that, the 10 most relevant articles were prioritized for qualitative analysis. Thus, the base of articles obtained through the application of the Method Ordination is shown in Table 3, with the respective authors and year, title, Journal and keywords.

\begin{tabular}{|c|c|c|c|c|}
\hline \# & Author & Title & Journal & key Words \\
\hline & $\begin{array}{c}\text { Patrizia Ghisellini a, Catia Cialanib, Sergio } \\
\text { Ulgiatic, } d(2016)\end{array}$ & $\begin{array}{c}\text { A review on circular economy: the } \\
\text { expected transition to a balanced } \\
\text { interplay of environmental and } \\
\text { economic systems }\end{array}$ & $\begin{array}{l}\text { Journal of Cleaner } \\
\text { Production }\end{array}$ & $\begin{array}{l}\text { Circular economy, } \\
\text { Resource efficiency, } \\
\text { Reuse, Recycling, Zero } \\
\text { waste, Sustainability }\end{array}$ \\
\hline 2 & Ford, Simon; Despeisse, Mélanie (2016) & $\begin{array}{c}\text { Additive manufacturing and } \\
\text { sustainability: an exploratory } \\
\text { study of the advantages and } \\
\text { challenges }\end{array}$ & $\begin{array}{l}\text { Journal of Cleaner } \\
\text { Production }\end{array}$ & $\begin{array}{l}\text { Additive manufacturing, 30 } \\
\text { printing, Industrial } \\
\text { sustainability, Resource } \\
\text { efficiency, Product life } \\
\text { cycle, Value chain } \\
\text { reconfiguration } \\
\end{array}$ \\
\hline 3 & Despeisse, M; Baumers, M. (2017) & $\begin{array}{l}\text { Unlocking value for a circular } \\
\text { economy through } 3 D \text { printing: A } \\
\text { research agenda }\end{array}$ & $\begin{array}{l}\text { Technological Forecasting } \\
\text { and Social Change }\end{array}$ & $\begin{array}{l}\text { 3D printing, Additive } \\
\text { manufacturing, Circular } \\
\text { economy, Sustainability, } \\
\text { Research agenda }\end{array}$ \\
\hline 4 & Rejeski, David; Zhao, Fu; Huang, Yong (2018) & $\begin{array}{l}\text { Research needs and } \\
\text { recommendations on } \\
\text { environmental implications of } \\
\text { additive manufacturing }\end{array}$ & Additive Manufacturing & $\begin{array}{l}\text { Additive manufacturing, } \\
\text { Environmental implication, } \\
\text { Research need, } \\
\text { Recommendation }\end{array}$ \\
\hline 5 & Cerdas, Felipe ar.3/ (2017) & $\begin{array}{l}\text { Life Cycle Assessment of } 3 \mathrm{D} \\
\text { PrintedProducts in a Distributed } \\
\text { Manufacturing System }\end{array}$ & Journal of Industrial Ecology & $\begin{array}{l}\text { 3D printing, additive } \\
\text { manufacturing, distributed } \\
\text { manufacturing, direct digital } \\
\text { manufacturing, industrial } \\
\text { ecology, life cycle } \\
\text { assessment (LCA) } \\
\end{array}$ \\
\hline 6 & Peng, T ar. $3 /$ (2018) & $\begin{array}{c}\text { Sustainability of additive } \\
\text { manufacturing: An overview on its } \\
\text { energy demand and } \\
\text { environmental impact }\end{array}$ & Additive Manufacturing & $\begin{array}{l}\text { Additive manufacturing, } \\
\text { Energy consumption, } \\
\text { Environmental impact, } \\
\text { Resource consumption, } \\
\text { Sustainable manufacturing }\end{array}$ \\
\hline 7 & $\begin{array}{l}\text { Garmulewicz, Alysia; Holweg, Matthias; } \\
\text { Veldhuis, Hans; Yang, Aidong (2018) }\end{array}$ & $\begin{array}{c}\text { Disruptive Technology as an } \\
\text { Enabler of the Circular Economy: } \\
\text { What Potential Does 3D Printing } \\
\text { Hold? }\end{array}$ & $\begin{array}{l}\text { california management } \\
\text { review }\end{array}$ & $\begin{array}{l}\text { circular economy, } \\
\text { technological innovation, } \\
\text { disruptive technology, 3D } \\
\text { printing }\end{array}$ \\
\hline 8 & $\begin{array}{l}\text { Sauerwein, Marita: Doubrouski, Eugeni; } \\
\text { Balkenende, Ruud; Bakker, Conny (2019) }\end{array}$ & $\begin{array}{l}\text { Exploring the potential of additive } \\
\text { manufacturing for product design } \\
\text { in a circular economy }\end{array}$ & $\begin{array}{l}\text { Journal of Cleaner } \\
\text { Production }\end{array}$ & $\begin{array}{l}\text { additive manufacturing, } \\
\text { circular economy, product } \\
\text { design, product life } \\
\text { extension, design for } \\
\text { sustainability, annotated } \\
\text { portfolios }\end{array}$ \\
\hline 9 & $\begin{array}{c}\text { Yang, Sheng Min, Wenbo Ghibaudo, Julian } \\
\text { Zhao, Yaoyao F. (2019) }\end{array}$ & $\begin{array}{l}\text { Understanding the sustainability } \\
\text { potential of part consolidation } \\
\text { design supported by additive } \\
\text { manufacturing }\end{array}$ & $\begin{array}{l}\text { Journal of Cleaner } \\
\text { Production }\end{array}$ & $\begin{array}{l}\text { Part consolidation, } \\
\text { Environmental impact, } \\
\text { Lifecycle analysis, Design } \\
\text { for additive manufacturing. } \\
\text { Assembly }\end{array}$ \\
\hline 10 & Gregory Unruh (2018) & $\begin{array}{l}\text { Circular Economy, 3D Printing. } \\
\text { and the Biosphere Rules }\end{array}$ & $\begin{array}{c}\text { California Management } \\
\text { Review }\end{array}$ & $\begin{array}{l}\text { circular economy, } \\
\text { disruptive technology, } \\
\text { sustainability }\end{array}$ \\
\hline
\end{tabular}

Table 3 : Base of articles based on the In Ordination calculation Source: Authors 
DOI: 10.14807/ijmp.v11i5.1290

In general, it can be seen from the articles analysis the current industrial applications of 3D printing are already enabling a circular production system with the use of recycled and recovered materials as an input for additive manufacturing processes. The process not only uses less material due to its additive nature (the material is added only when necessary), but the system around the process is designed to allow material loop.

Therefore, additive manufacturing has been identified as having the potential to provide several sustainability advantages. These advantages include the generation of less waste during manufacture; the ability to optimize geometries and create lightweight components that reduce material consumption in manufacturing and energy consumption in use; the subsequent reduction in transportation in the supply chain; and reduced inventory waste due to the ability to create spare parts on demand.

Despite this, Rejeski et al. (2018), in his work on the environmental implications of Additive Manufacturing, summarizes the current state of the art and research needs and points out that AM can announce the apotheosis of consumerism, instant gratification and the disposable society. All of this can have negative impacts on the environment.

In addition to this work, which points out research needs in the area, the research by Despeisse et al. (2017) also presents a research agenda to explore the means by which 3D printing can enable more sustainable modes of production and consumption and unlock value in the circular economy. The article explores six areas of research identified as critical to understanding how 3D printing can enable them for a CE, namely: (1) product, service and system design, (2) material supply chains, (3) information structure and flows, (4) entrepreneurial responses, (5) business model transformations and (6) skills and education development.

Ford and Despeisse (2016) discuss how AM creates opportunities for sustainability and what types of organizations are doing them. They also discuss the possible sustainability benefits that may arise in the future through the adoption of new business models and the redistribution of manufacturing. They investigated the adoption of AM from a life cycle perspective. Four main categories have been identified in which MA is enabling sustainability benefits to be achieved: redesign of products and processes; material input processing; manufacture of components and products to order; and closing the loop.

In spite of the aforementioned authors conclude that AM is inherently a technology which will support sustainable production and consumption, they reveal the role played by AM in the transition to a more sustainable industrial system remains uncertain. According to them, its adoption and application can safeguard dangers and unintended consequences from negative 
DOI: 10.14807/ijmp.v11i5.1290

impacts to sustainability. In this way, they make it clear that although the benefits of sustainability are evident, there are also substantial challenges, among them: high volumes of machinery costs; lack of knowledge and understanding of the environmental performance of technologies, supply chains and products manufactured through AM; AM integration with hybrid technologies in design ; and limited automation production.

Garmulewicz et al. (2018) also identifies as opportunities and barriers that 3D printing imposes on the Circular Economy. Thus, they pose a question of whether or not 3D printing can act as a facilitator of the circular economy. His findings confirm that 3D printing, in fact, has a strong potential for acting as a facilitator of the circular economy for three reasons. First, 3D printing has the potential to alter the economics of the existing manufacturing value chain, so, at least in principle, it can enable economically viable small-scale local production. Second, all the technologies needed to collect and process waste plastics to transform primary 3D printing materials are now available. Third, waste streams can provide plastic raw materials of minimal quality and quantity.

In addition, Garmulewicz et al. (2018) offers a vision of how the circular economy could affect Additive Manufacturing through the recycling of plastic materials for 3D printing. The technologies needed to transform plastic waste into raw material for 3D printing are available today, albeit on a small experimental scale. In addition, some technological barriers were cited. First, the functional quality of 3D printed products, their high cost and, in turn, the limited consumer demand for these recycled products were mentioned. The group reached a consensus that this represented the biggest barrier of all, but also recognized the fast pace of innovation in printing technology. In addition, the general lack of suitable materials for recycling to be used in 3D printing and the availability of local materials were seen as a major barrier.

Sauerwein et al. (2019) and Yang et al. (2019) explore the AM opportunities for sustainable design. The first explores if AM opportunities for sustainable design are also useful when designing for a circular economy. Also, it is explored the extent to which AM can support design for a circular economy. The second, develops a comprehensive decision support tool to select a more sustainable assembly design solution in the initial product design stage.

Sauerwein et al. (2019), through an analysis of design projects, shows that AM creates opportunities to allow circular design strategies, such as updates and repairs which extend the life of a product, even if they have not been considered in the original product design. This can be attributed to characteristics of AM, such as digital production and adaptability and digital product files which allow changes and repair. This is essential for extending product life. 
DOI: 10.14807/ijmp.v11i5.1290

Peng et al. (2018) studies the issue of sustainability in AM, focusing on its environmental impact. The study provides the latest developments on the Sustainability of Additive Manufacturing. In this work, the context of sustainability was introduced and elaborated with a focus on energy demand and environmental impact.

Cerdas et al. (2017) compares two different ways to manufacture a product that offers the same equivalent function. Using glasses frames as an example, the environmental implications related to the 3D printed product produced under a distributed manufacturing system (DMSs) and the equivalent product manufactured in a conventional centralized manufacturing system are investigated. Although the general results of the study do not indicate precisely whether one production system has potential environmental advantages over the other, this article identified the main relevant aspects in a DMS to understand how this technology can also impact the environment.

Finally, Unruh (2018) proposes a guide for the implementation of a CE built on a 3D printing base. The author brings together two fields in an existing structure - the rules of the biosphere and an industrial model inspired by ecology.

\section{CONCLUSIONS}

This work approached how Additive Manufacturing and Circular Economy are related. The results showed many opportunities for future research, since the subject is not yet at an advanced stage. Initial studies indicated that Additive Manufacturing has the potential to provide the advantages of sustainability and the circular production system. However, more recent studies have highlighted some barriers that can prevent this vision from becoming a reality.

Other studies have indicated that AM may evolve into a trend to encourage consumerism, instant gratification and disposable society, which also goes against the principles of circular economy. Among the 10 studies analyzed, only one showed how circular economy is capable of enhancing additive manufacturing with the idea of recycling plastic materials for 3D printing. The same study, however, highlights the barriers found for such an idea.

Regarding the limitations of the work, it wasn't used a software for content analysis and it was only analyzed ten articles so far.

\section{ACKNOWLEDGMENT}


DOI: 10.14807/ijmp.v11i5.1290

This work was carried out with the support of the Coordination for the Improvement of Higher Education Personnel - Brazil (CAPES) - Financing Code 001.

\section{REFERENCES}

ANDERSEN, M. S. (2007) An introductory note on the environmental economics of the circular economy, Sustainability Science, v. 2, n. 1, p. 133-140.

ANTELMAN, K. (2004) Do open-access articles have a greater research impact? College \& research libraries, v. 65, n. 5, p. 372-382.

ASTM. Standard Terminology for Additive Manufacturing Technologies (2013) [s.l.]

American Society for Testing and Materials - ASTM.

BADGER, D.; NURSTEN, J.; WILLIAMS, P.; WOODWARD, D. (2000) Should all literature reviews be systematic? Evaluation \& Research in Education, v. 14, n. 3-4, p. 220-230.

BANDYOPADDHYAY, A.; GUALTIERI T. P.; BOSE S. (2015) Global engineering and additive manufacturing, Additive Manufacturing, v. 1, p. 9-11.

BIOLCHINI, J.; MIAN, P. G.; NATALI A. C. C.; TRAVASSOS G. H. (2005) Systematic review in software engineering. System Engineering and Computer Science Department COPPE/UFRJ, Technical Report ES, v. 679, n. 05, p. 45.

BORNMAN, L. (2010) Towards an ideal method of measuring research performance: Some comments to the Opthof and Leydesdorff, Journal of Informetrics, v. 3, n. 4, p. 441-443.

BOURELL, D. L.; ROSEN, D. W.; LEU, M. C. (2014) The roadmap for additive manufacturing and its impact, 3D Printing and Additive Manufacturing, v. 1, n. 1, p. 6-9.

BUER, S.; STRANDHAGEN; JAN, O.; CHAN, F. T. S. (2018) The link between Industry 4.0 and lean manufacturing: mapping current research and establishing a research agenda, International Journal of Production Research, v. 56, n. 8, p. 2924-2940.

CERDAS, F.; JURASCHEK, S.; THIEDE, C.; HERRMAN, C. (2017) Life cycle assessment of 3D printed products in a distributed manufacturing system, Journal of Industrial

Ecology, v. 21, n. S1, p. S80-S93, doi: 10.1111/jiec.12618

COOPER, H. M. (1998) Synthesizing research: A guide for literature reviews. Sage.

DESPEISSE, M.; BAUMERS, M.; BROWN, P.; CHARNLEY, F.; FORD, S.;

GARMULEWICZ A.; KNOWLES, S.; MINSHALL, T. H. W.; MORTARA, L.; REEDTSOCHAS, F. P.; ROWLEY, J. (2017) Unlocking value for a circular economy through 3D printing: A research agenda, Technological Forecasting and Social Change, v. 115, p. 7584, doi: 10.1016/j.techfore.2016.09.021

DURIAU, V. J.; REGER, R. K.; PFARRER, M. D. (2007) A content analysis of the content analysis literature in organization studies: Research themes, data sources, and methodological refinements, Organizational research methods, v. 10, n. 1, p. 5-34.

EVANS, S.; GREGORY, M.; RYAN, C.; BERGENDAHL, M. N.; TAN, A. (2009) Towards a sustainable industrial system: With recommendations for education, research, industry and policy, University of Cambridge, Institute for Manufacturing.

FORD, S.; DESPEISSE, M. (2016) Additive manufacturing and sustainability: an exploratory study of the advantages and challenges, Journal of Cleaner Production, v. 137, p. 15731587. 
GARMULEWICZ, A.; HOLWEG, M.; VELDHUIS, H.; YANG, A. (2018) Disruptive technology as an enabler of the circular economy: what potential does 3D printing hold?, California Management Review, v. 60, n. 3, p. 112-132.

GHISELLINI, P.; CIALANI, C.; ULGIATI, S. (2016) A review on circular economy: the expected transition to a balanced interplay of environmental and economic systems, Journal of Cleaner production, v. 114, p. 11-32.

GRESS, D. R.; KALAFSKY, R. V. (2015) Geographies of production in 3D: Theoretical and research implications stemming from additive manufacturing, Geoforum, v. 60, p. 43-52.

HOLWEG, M. (2015) The limits of 3-D printing, Harvard Business Review.

JABBOUR, A. B. L. S.; JABBOUR, C. J. C.; GODINHO FILHO, M.; ROUBAUD, D. (2018) Industry 4.0 and the circular economy: a proposed research agenda and original roadmap for sustainable operations, Annals of Operations Research, v. 270, n. 1-2, p. 273286, doi: 10.1007/s10479-018-2772-8.

KANG, H. S.; LEE, J. Y.; CHOI, S.; KIM, H.; PARK, J. H.; SON J. Y.; KIM, B. H.; DO NOH, S. (2016) Smart manufacturing: Past research, present findings, and future directions, International Journal of Precision Engineering and Manufacturing-Green Technology, v. 3, n. 1, p. 111-128, doi: 10.1007/s40684-016-0015-5

KIETZMANN, J.; PITT, L.; BERTHON, P. (2015) Disruptions, decisions, and destinations: Enter the age of 3-D printing and additive manufacturing, Business Horizons, v. 58, n. 2, p. 209-215.

KRIPPENDORFF, K. (2018) Content analysis: An introduction to its methodology, Sage publications.

LASI, H.; FETTKE, P.; KEMPER, H. G; FELD, T.; HOFFMANN M. (2014) Industry 4.0.

Business \& information systems engineering, v. 6, n. 4, p. 239-242.

LOY, J.; TATHAM, P. (2016) Redesigning production systems, In: Handbook of

Sustainability in Additive Manufacturing, Springer, Singapore. p. 145-168.

MACARTHUR, E. (2013) Towards the circular economy, Journal of Industrial Ecology, v. 2, p. 23-44.

MATHEUS, J. A.; TAN, H. (2011) Progress toward a circular economy in China: The drivers (and inhibitors) of eco-industrial initiative, Journal of industrial ecology, v. 15, n. 3, p. 435457.

MOHER, D.; LIBERATI, A.; TETZLAFF, J.; ALTMAN, D. G. (2009) Preferred reporting items for systematic reviews and meta-analyses: the PRISMA statement, Annals of internal medicine, v. 151, n. 4, p. 264-269.

NUMAN, H. J.; SARLIN, P. (2014) From bits to atoms: 3D printing in the context of supply chain strategies, In: 2014 47th Hawaii International Conference on System Sciences, IEEE. p. 4190-4199.

PAGANI, R. N.; KOVALESKI, J. L.; RESENDE, L. M. (2015) Methodi Ordinatio: a proposed methodology to select and rank relevant scientific papers encompassing the impact factor, number of citation, and year of publication, Scientometrics, v. 105, n. 3, p. 21092135.

PENG, T.; KELLENS, K; TANG, R.; CHEN, C.; CHEN, G. (2018) Sustainability of additive manufacturing: An overview on its energy demand and environmental impact. Additive Manufacturing, v. 21, p. 694-704. 
PETROVIC, V.; GONZALEZ, A. H. J.; FORDÁ, F. O.; GORDILLO, J.; PUSHADES, J.; GRIÑAN L. (2011) Additive layered manufacturing: sectors of industrial application shown through case studies, International Journal of Production Research, v. 49, n. 4, p. 10611079.

REJESKI, D.; ZHAO, F.; HUANG, Y. (2018) Research needs and recommendations on environmental implications of additive manufacturing, Additive Manufacturing, v. 19, p. 21-28.

RUFFO, M.; TUCK, C.; HAGUE, R. (2006) Cost estimation for rapid manufacturing-laser sintering production for low to medium volumes, Proceedings of the Institution of Mechanical Engineers, Part B: Journal of Engineering Manufacture, v. 220, n. 9, p. 1417-1427.

SAUERWEIN, M.; DOUBROVSKI, E.; BALKENENDE, R.; BAKKER, C. (2019)

Exploring the potential of additive manufacturing for product design in a circular economy, Journal of Cleaner Production, v. 226, p. 1138-1149.

SHIPP, S. S.; GUPTA, N.; LAL, B.; SCOTT, J. A.; WEBER, C. L.; FINNIN, M. S.; BLAKE, M.; NEWSOME, S.; THOMAS, S. (2012) Emerging global trends in advanced manufacturing. Institute For Defense Analyses Alexandria Va. FFRDC: Science and Technology Policy Institute. IDA document: P-4603.

SHROUF, F.; ORDIERES, J.; MIRAGLIOTTA, G. (2014) Smart factories in Industry 4.0: A review of the concept and of energy management approached in production based on the Internet of Things paradigm, In: 2014 IEEE international conference on industrial engineering and engineering management. IEEE, p. 697-701.

SIN, M. L. (2016) Achieving ship's mission flexibility through designing, printing and operating unmanned systems with additive manufacturing and delayed differentiation, Tese de Doutorado. Monterey, California: Naval Postgraduate School.

TRANFIELD, D.; DENYER, D.; SMART, P. (2003) Towards a methodology for developing evidence-informed management knowledge by means of systematic review. British journal of management, v. 14, n. 3, p. 207-222.

UNRUH, G. (2018) Circular economy, 3D printing, and the biosphere rules. California Management Review, v. 60, n. 3, p. 95-111.

VINKLER, P. (2012) The case of scientometricians with the "absolute relative" impact indicator. Journal of Informetrics, v. 6, n. 2, p. 254-264.

YANG, S.; MIN, W.; GHIBAUDO, J.; ZHAO, Y. F. (2019) Understanding the sustainability potential of part consolidation design supported by additive manufacturing, Journal of Cleaner Production, v. 232, p.722-738.

YUAN, Z.; BI, J.; MORIGUICHI, Y. (2006) The circular economy: A new development strategy in China, Journal of Industrial Ecology, v. 10, n. 1-2, p. 4-8.

ZHAI, Y.; LADOS, D. A.; LAGOY, J. L. (2014) Additive manufacturing: making imagination the major limitation, Journal of Management, v. 66, n. 5, p. 808-816 